\title{
Solving Complex Problems with Help of Experiential Learning
}

\author{
Mojca Bernik, Jasmina Žnidaršič \\ University of Maribor, Faculty of Organizational Science, Kidričeva 55a, 4000 Kranj, Slovenia, \\ mojca.bernik@fov.uni-mb.si, jasmina.znidarsic@fov.uni-mb.si
}

This paper presents the impact of experiential learning on solving complex problems. Analyzed are methods and techniques of experiential learning as an active form of learning. Presented are the results of research in which we examine whether the systematic approach of problem solving differs between the genders, if the perception of experience as a source of knowledge depends on the level of education, and examine a correlation between searching of all possible ways for successful problems solving and perception of experience as a source of knowledge.

Keywords: complex problem, human resource, training, experiential learning

\section{Introduction}

Everyday tasks in the workplace require suitably qualified individual who either brought his knowledge with him to the organization or have obtained it during the employment. In the first case, the school system is responsible for appropriate educational programs covering a wide range of knowledge, in the second case, the organization is the one that should take care to meet the individuals' needs of a specific knowledge. We could say that the continuing education and organization's development are directly linked with each other. This means that systematic approach is needed to the process of training, acquisition of knowledge and skills required to achieve the objectives of organization and its development. However, at this point it also must be emphasized that each individual is responsible for both their education and career planning.

By entering the information society the accessibility of information has increased and with it the possibility of using different ways of staff training. Active forms of learning are increasingly replacing the traditional passive forms, by which the use of technology enables interactivity between individuals and learning content. The individual is the one who can choose the time, learning speed and the way that is suitable for him and his needs. Lack of time and the saturation of the individual with information can lead to frustration and consequently to the failure in achieving the set goals. To avoid that a systematic approach is needed to solve both simple and complex problems. That means first of all the identification of the detected problem, the possibility of its solving and search of information that we lack for adequate problem solving. In doing so, organizations use different methods of staff training with the aim of employees' capability to solve complex problems they face at workplace constructively and effectively.

The main aim of this paper is therefore to determine how in general individuals solve problems in their lives, and whether they use previous experiences as help in solving the problems.

\section{Theoretical background}

\subsection{Defining complex problems}

Complex problems characterized the problem situation of many different, strongly linked influential quantities of which interaction will be further changing. The main feature of complex problems is therefore the dynamic, the appearance of always new patterns and their mutual relationships (Rosi and Mulej, 2006).

One of the main characteristics of complex problems is their dimensions, which require for their solution the integration of several players with different skills. Complex problems rarely occur quickly and also the available time that the decision makers have for decision is usually longer than for solving simple problems. Therefore, solving complex problems often takes place in groups, teams, because it frequently happens that the current solution turns out to be a new problem. Interconnection of variables within a complex problem can

Received: $19^{\text {th }}$ January 2012; revised $18^{\text {th }}$ February 2012; accepted $28^{\text {th }}$ March 2012 
also be so extensive, that that the problem in specific time shows to be unsolvable.

The process of complex problem solving must be a process of integration of qualitative analysis and quantitative analysis (Chen and Ding, 2010). The solution is based on qualitative and quantitative knowledge of the decision maker. Qualitative knowledge includes problem knowledge, meanwhile quantitative knowledge includes the model knowledge.

Furthermore, Tuan (2003) argues, that a complex problem consists of two parts: human's incapacity of mental power and human's cognitive dissonance. The complexity is in the observer's mind. The disparate mental activities and the limitations of human's mental power are the sources that lead to dissonance and conflict.

\subsection{Methods of solving complex problems}

Solving complex problems is a logical process that begins by determination of the problem, continues with analysis what led to unwanted results, noting the individual causes and ends with the decision, an action needs to be done to solve the problem, which is the undesirable situation. We can say that the problem remains, if the resulting state differs significantly from the established state. In other words, if the current situation deviates substantially from what it should be. It is necessary to determine the event or cause that led to the current situation. Just appropriate actions based on an accurate definition of the causes are likely to lead to the goals, improvements.

What exactly we do when we analyze and solve complex problems? In fact, we evaluate previous work and outline the way ahead. We ask ourselves questions that would lead us to the findings and way forward. This requires considerable data and all the correlated information, particularly those that show us the cause of the problem and those that exclude the cause of the problem.

Ability to identify the causes of occurring state is particularly important if we are under pressure of time and work. Then it happens often that we quickly search for a solution and we believe to the first reason, just to get rid of the problem, but usually then find ourselves in a new, more complex problem. It is therefore important to know the appropriate work method. We also have to beat least generally familiar with our work and we have to know where our place is. On this basis we than know what information is relevant (correlated) for us, as well as which we are missing and we have to obtain.

One way of the complex problem solving is reinforcement learning, which is important mechanism in machine learning. Usually solutions involve multiple steps and actions which mean that number of possibilities grows. Reinforcement approaches define problems in a compatible way using algorithms concepts such as states, actions, goals, constraints, costs and distances (Dandurand, Shultz, Rivest, 2007).

We could say that generally in the process of solving complex problems, we distinguish two parts, namely, analyzing problems and making decisions. In both parts we have more levels, which are interconnected. Analysis of problems includes the following steps:
1. First it is necessary to determine what should be achieved; that is an expected standard and then compares it with the actual progress.

2. The problem, which is the deviation from the expected standard, should be precisely defined in terms of content, location, timing and distribution.

3. The cause of the problem is always an event; change, the conditions that led to the unwanted situation. It is necessary to identify and distinguish between what is related to the problem and what is not related to the problem.

4. It is necessary to determine possible causes, consider them according to the information and credibility and gradually move towards the most probable cause.

5. The most likely cause is the one that for the most part explain all the facts and data concerning the occurrence of a specific problem.

Once we define and analyze complex problems, we yet have to adopt a suitable solution to address the problem. Decision-making includes the following steps:

1. Based on the identified situation and the causes, it is necessary to set a goal, decision or action that is in this context.

2. We define a goal regarding of what we have to and what we can achieve.

3. It is necessary to determine possible ways, and alternative actions, that could lead to the goal.

4. We compare possible ways, an alternative action, to each other and evaluated those regarding set goals in light of what we must and can do within an existing organization.

5. Choose the most appropriate way, an action, which is the decision. The most appropriate decision is the one that contains the least undesirable consequences.

Because complex problems cover a number of interrelated changing events, systematically approach to address them is necessary. That means that we have to use appropriate methods, such as experiential learning which is described below.

The complex problem solving can be found in many research fields. It can be used for educational purpose as case studies (Leppävirta, Kettunen and Sihvola, 2011), design engineering (Cavallucci and Eltzer, 2011), cognitivity (Kim, 2012; Dandurand, Shultz and Rey, 2012), decision support system (Klashner and Sabet, 2007) as in many others research fields.

One of them is individual's ability to learn and solve problems. The connection between learning and problem solving can influence the employee performance (Tews, Michel and Noe, 2011). Organizations tend to have strong employee performance to achieve strategically goals. One parameter of employee performance is efficiency of complex problem solving.

\subsection{Human resource learning and complex problem}

Daily employees face problems which they have to solve in the workplace. Problem solving is on one hand related to decision-making and setting goals of the organization, and 
on the other hand is related with education and competence of individuals to solve problems. The transformations taking place in society and in organizations require an increasing participation of the individual, an ability to innovate and solve problem, a capacity to learn and opportunity to continue with learning (Žnidaršič and Jereb, 2011).

Organizations need and expect a successful employee, who is every day gaining new knowledge, on the one hand, from practice, from experiences of solving (past) problems, and on the other hand, from theoretical finding and generalization or even others' experiences. Often it turns out that the actual practice is often ahead of theoretical knowledge and so individuals are trained on the basis of informal knowledge obtained with experiences, and not on the basis of knowledge acquired through formal education or theoretical knowledge (Možina, 1991). Even better is that theoretical and practical knowledge are connected, in this case we talk about active learning.

Numerous studies have confirmed that the learning which integrate individual, mentally and emotionally activate him and is personally meaningful and integrated into real life situations, is more effective. Moreover, such learning will give sustainable knowledge that will also be useful in new situations (Marentič Požarnik, 2000). And such learning is active learning. Chickering and Gamson (1987) point out that students with a passive form of learning where they just listen and try to remember the content do not learn much, therefore, they propose that students should be more actively involved in the learning process. About learned they have to talk, write, discuss, and integrate what they have learned with past experiences and they also have to be involved in solving problems. Bonwell and Eison (1991) further add that students should be involved in complex mental processes such as analysis, synthesis and evaluation.

The traditional concept of education that encourages passive forms of learning is no longer adequate or sufficient, especially for education of adults, who already have some practical experience gained with working at particular workplace. Nuissl (2006) points out that the adults in the educational process today more than in the past expect from teachers to take in account their already acquired knowledge and their ability to articulate and communicate it. Adults in the educational process require active learning, which allow them greater understanding and preservation of information that can then be used in different situations and at solving problems in the future.

Active learning includes all learning methods, where student participates actively (Keyser, 2000). One of the common methods of active learning is an experiential learning.

\subsection{Methods and techniques of experiential learning}

Jarvis (2003) defines experiential learning as a process by which individuals either create or attempt to create meaning on the basis of situations that they are aware of, and then pursue to remember that and transform or integrate results into their life experience.
Experiential learning is therefore on the experience based learning of theory (Fowler, 2007). It is a bridge between theoretical and practical knowledge, or with other words, it links skills gained from literature and lectures with knowledge based on experiences gained through the real life. For experiential learning is important an active involvement in the overall experience, for example, in group events, and at the same time thinking, reflection on experience. The basic assumption of experiential learning is that we learn best if we do something. A central role plays the comprehensive personal experience (Marentič Požarnik, 2000).

Erzar Metelko (1999) says that an experiential learning is a quality and an integrated process of further learning, training and personal growth. Analysis of the experiential learning concept shows that the product of reflection based on experience, including the nature of reflection and quality of experience, is important for general education (Fowler, 2007).

Kolb (summarized from Erzar Metelko, 1999) argues that experiential learning consists of four stages: concrete experience, reflective observation and reflection, the formation of concepts and abstract generalization, and testing of new recognition and generalization to new situations. These rates are repeating and linking in the process of experiential learning. As Kolb argue, the experiential learning is therefore a process in which occurs a creation of knowledge based on changes of experiences and changes in thinking and direct and considered perception of experience (summarized from Erzar Metelko, 1999).

There are many methods of experiential learning. Walter and Marks (1981, summarized from Erzar Metelko, 1999) divide them into the central methods (group interaction, simulation method, the role-play method, brainstorming, etc..), support methods (guided imagination, use of audiovisual means, the process observation) and classical methods (lecture, work with text, writing, case study). But we have to point out that there are stated also some methods that today are no longer classified as experiential learning (eg, lecture).

Marentič Požarnik (2000) divides experiential learning methods into the central methods (simulations, role playing and social games, structured games, group interaction and physical exercise, and relaxation), and support methods (process observation, the time for consideration, fantasy and visualization, terrain experience, excursion, case method, project method and the use of audiovisual means).

The teacher has an important role in implementing and planning experiential learning, and that requires great skills. Teacher must be able to empathize in participants, have to ask himself which areas in participants would like to touch, what are the aims and purposes, but also have to take into account the circumstances - what they are, on which they can influence and on which they cannot (Marentič Požarnik, 2000). One way of achieving these goals is using problem - based learning (PBL) theory, which offers a strong framework that allows all participants to learn real-world, and globally competitive problem solving skills (Pierrakos et al., 2010). 


\section{Methodology}

\subsection{Hypotheses}

Through the research we wanted to test next hypothesis:

H1: There are no differences in the average of systematic approach to problem solving between the genders

$\mathrm{H} 2$ : Perception of experience as a source of knowledge varies depending on the level of education

H3: There is positive correlation between searching of all possible ways for successful decision and positive experience with solving problems

H4: There is positive correlation between perception of experience as a source of knowledge and positive experience with solving problems

\subsection{Instrument and variables}

We tested our hypotheses through a questionnaire. The study was conducted in November 2011. The questionnaire was of the closed type and anonymous.

The questionnaire comprised 31 questions relating to (1) data on the respondent (gender, age and education), (2) factors relating to analyzing problems, (3) factors relating to using experience in solving the problem and (4) factors relating to decision-making.

Variables used in our research are the following:

1. General data

S1 Gender

S2 Age

S3 Education

2. Problems analyzing

S4 I can notice a serious problem

S5 I confront the problem

S6 I approach to the problem systematically

S7 The problem upsets me

S8 The problem is a challenge for me

S9 I take time to explore causes of the problem

S10 I analyze causes of the problem by relevance

S11 I analyze consequences of the unresolved problem

S12 I consult with colleagues about the causes of the problem

S13 I am not bothered with others' problems

3. Using experience in solving problems

S14 At the problem I am looking of parallels with similar problems in the past

S15 Experience with solving problems in the past personally enriching me

S16 I had positive experience with solving problems in the past

S17 I solve problems with help of associates' experience

S18 I forget the problem and its solution in the past S19 Experiences are a source of my knowledge

S20 I keep going back to the to the analysis of past problems

S21 I doubt in my previous decisions
4. Decision making

S22 Before deciding I set myself the goal that I want to achieve

S23 I analyze situations that I can avoid at decisionmaking

S24 I search for all possible ways for successful decision

S25 I analyze ways and evaluate them in terms of performance for successful decision

S26 Of all the ways leading to the decision to decide for the fastest

S27 Of all the ways leading to the decision to decide for the least harmful

S28 I search for new information before decisionmaking

S29 When I decide I do not think anymore about the decision

S30 I take time for decision-making

S31 Before I decide I discuss with associates

Respondent's perceptions (questions S4 to S31) were measured on a scale ranging from 1 to 5 where: 1 - never, 2 rarely, 3 - sometimes, 4 - often, 5 - always.

For questions 4 to 28 the Cronbach's alpha coefficient was calculated. The value was 0.684 which indicates good reliability of measurement. With regard to the composition and characteristics of the sample, we believe that it is representative.

\subsection{Sample}

Participants in this study were employees from different sectors (industry, service and educational institutions). They were selected randomly and participation was voluntary. The sample consisted of $26(52 \%)$ women and $24(48 \%)$ men $(\mathrm{N}=50)$. The age range of respondents was between 20 and 60 years, where 17 respondents were below 21 years old (34\%), 12 between 21 and 30 years (24\%), 11 between 31 and 40 years (11\%), 8 between 41 and $50(8 \%)$ and 2 respondents were more than 51 years old $(2 \%)$. The education of respondents was from secondary education to $\mathrm{PhD}$.

\subsection{Results}

We begin by constructing the frequency tables (Table 1) for the variables we have used in our research.

The first set of statements referred to the problems analyzing. Respondents' answers were fairly different. Answers varied the most at the question of whether they consult with colleagues about the cause of the problem (S9). The arithmetic mean at this question is 3.26 with a standard deviation of .986. Most alike were respondents at the first argument (S1), if they can detect a serious problem. At that question they only answered the questions with answers sometimes, often and always (Mean=3.92, Std. Deviation .528).

The second set of statements referred to the using experience in solving the problem. Again the answers were quite spread. Most responses have differed on the question if experiences with problem solving in the past personally enrich- 
Table 1: Frequency tables for the variables

\begin{tabular}{|c|c|c|c|c|c|c|c|}
\hline & \multicolumn{2}{|c|}{$\mathrm{N}$} & \multirow[t]{2}{*}{ Mean } & \multirow[t]{2}{*}{ Median } & \multirow{2}{*}{$\begin{array}{c}\text { Std. } \\
\text { Deviation }\end{array}$} & \multirow[t]{2}{*}{ Minimum } & \multirow[t]{2}{*}{ Maximum } \\
\hline & Valid & Missing & & & & & \\
\hline \multicolumn{8}{|c|}{ Analyzing problem } \\
\hline $\mathrm{S} 4$ & 50 & 0 & 3,92 & $3,91^{\mathrm{a}}$ &, 528 & 3 & 5 \\
\hline S5 & 50 & 0 & 3,98 & $4,00^{\mathrm{a}}$ & ,654 & 2 & 5 \\
\hline S6 & 50 & 0 & 3,66 & $3,61^{\mathrm{a}}$ &, 772 & 2 & 5 \\
\hline S7 & 50 & 0 & 2,84 & $2,80^{\mathrm{a}}$ & ,792 & 1 & 5 \\
\hline S8 & 50 & 0 & 3,20 & $3,21^{\mathrm{a}}$ & ,857 & 1 & 5 \\
\hline S9 & 50 & 0 & 3,34 & $3,38^{\mathrm{a}}$ & ,848 & 1 & 5 \\
\hline S10 & 50 & 0 & 2,96 & $2,94^{\mathrm{a}}$ & ,880 & 1 & 5 \\
\hline S11 & 50 & 0 & 3,26 & $3,31^{\mathrm{a}}$ & ,965 & 1 & 5 \\
\hline S12 & 50 & 0 & 3,26 & $3,31^{\mathrm{a}}$ & ,986 & 1 & 5 \\
\hline S13 & 50 & 0 & 3,04 & $3,06^{\mathrm{a}}$ & ,903 & 1 & 5 \\
\hline \multicolumn{8}{|c|}{ Using experience in solving the problem } \\
\hline S14 & 50 & 0 & 3,72 & $3,75^{\mathrm{a}}$ & ,882 & 2 & 5 \\
\hline S15 & 50 & 0 & 3,94 & $4,05^{\mathrm{a}}$ & ,913 & 2 & 5 \\
\hline S16 & 50 & 0 & 3,52 & $3,53^{\mathrm{a}}$ & 614 & 2 & 5 \\
\hline S17 & 50 & 0 & 3,08 & $3,12^{\mathrm{a}}$ & 829 & 1 & 5 \\
\hline S18 & 50 & 0 & 2,52 & $2,47^{\mathrm{a}}$ & ,909 & 1 & 4 \\
\hline S19 & 50 & 0 & 3,98 & $4,06^{\mathrm{a}}$ & ,892 & 2 & 5 \\
\hline S20 & 50 & 0 & 2,54 & $2,55^{\mathrm{a}}$ &, 813 & 1 & 4 \\
\hline S21 & 50 & 0 & 2,40 & $2,40^{\mathrm{a}}$ & ,756 & 1 & 4 \\
\hline \multicolumn{8}{|c|}{ Decision making } \\
\hline S22 & 50 & 0 & 3,90 & $3,91^{\mathrm{a}}$ & ,839 & 2 & 5 \\
\hline S23 & 50 & 0 & 3,46 & $3,50^{\mathrm{a}}$ & ,813 & 1 & 5 \\
\hline S24 & 50 & 0 & 3,72 & $3,74^{\mathrm{a}}$ & ,809 & 2 & 5 \\
\hline S25 & 50 & 0 & 3,10 & $3,17^{\mathrm{a}}$ & ,763 & 1 & 4 \\
\hline S26 & 50 & 0 & 3,14 & $3,15^{\mathrm{a}}$ & ,969 & 1 & 5 \\
\hline S27 & 50 & 0 & 3,72 & $3,73^{\mathrm{a}}$ &, 757 & 2 & 5 \\
\hline S28 & 50 & 0 & 3,76 & $3,84^{\mathrm{a}}$ & ,894 & 1 & 5 \\
\hline S29 & 50 & 0 & 3,24 & $3,21^{\mathrm{a}}$ & ,916 & 2 & 5 \\
\hline S30 & 50 & 0 & 3,60 & $3,62^{\mathrm{a}}$ & ,756 & 2 & 5 \\
\hline S31 & 50 & 0 & 3,04 & $3,11^{\mathrm{a}}$ & ,880 & 1 & 5 \\
\hline
\end{tabular}

a. Calculated from grouped data. 
Table 2: T test for hypothesis one

\begin{tabular}{|c|c|c|c|c|c|c|c|c|}
\hline \multicolumn{9}{|c|}{ Independent Samples Test } \\
\hline & & \multicolumn{2}{|c|}{$\begin{array}{l}\text { Levene's Test for } \\
\text { Equality of Variances }\end{array}$} & \multicolumn{5}{|c|}{ t-test for Equality of Means } \\
\hline & & $\mathrm{F}$ & Sig. & $\mathrm{t}$ & $\mathrm{df}$ & $\begin{array}{c}\text { Sig. } \\
\text { (2-tailed) }\end{array}$ & $\begin{array}{c}\text { Mean } \\
\text { Difference }\end{array}$ & $\begin{array}{l}\text { Std. Error } \\
\text { Difference }\end{array}$ \\
\hline \multirow{2}{*}{ S6 } & $\begin{array}{l}\text { Equal variances } \\
\text { assumed }\end{array}$ &, 006 & ,940 &,- 671 & 48 &, 506 &,- 147 &, 220 \\
\hline & $\begin{array}{c}\text { Equal variances not } \\
\text { assumed }\end{array}$ & & &,- 671 & 47,701 &, 506 &,- 147 & ,220 \\
\hline
\end{tabular}

ing them (S12), although none of the respondents answered this question with never. Mean at this question is 3.94, Std. Deviation is .913. The most common responses were at the question of whether they have positive experience with solving problems in the past, where also none of the respondents answer with the answer never (Mean is 3.52, Std. Deviation is .614).

The last set of statements referred to the decision-making. Most responses have differed on the question of whether of all of the ways leading to the decision they choose the fastest. Here the Std. Deviation is .969, Mean 3.14. For none of the question in this set the respondents have not been uniform.

In our research we assumed that there are no differences in the average of systematic approach to problem solving between the genders (H1). To test this hypothesis we used Independent-Samples T Test. As we can see in Table 2 there are no statistically significant differences between genders regarding systematic approach to problem solving.

Further we assumed that perception of experience as a source of knowledge varies depending on the level of education (H2). One-Way ANOVA was used to test this hypothesis. As we can see in Table 3 perception of experience as a source of knowledge differed significantly between education levels, $F(5,44)=7.075, p=.000$.

In our research we also assumed that there is a positive correlation between searching all possible ways for successful decision and positive experience with solving problems (H3). We tested hypotheses with Pearson's correlation coefficient and confirmed the correlation at 0,01 level $(\mathrm{r}=318)$.

In the last hypotheses we assumed that there is positive correlation between perception of experience as a source of knowledge and positive experience with solving problems
(H4). We tested hypotheses with Pearson's correlation coefficient and confirmed the correlation at 0,01 level $(r=318)$.

\section{Discussion}

Our research shows that most respondents can detect a serious problem and they have faced with the problem. They also mainly believe that their experiences in solving problems personally enrich them and that experiences are source of their knowledge. Before decision-making they set a goal they want to achieve.

First we tried to find out if there is any difference in systematic approach to problem solving between women and men. From our research and data collected in our survey we have found out that there is no statistically significant difference between genders regarding systematic approach to problem solving. Through Independent Sample T Test we verified our first hypothesis.

Our second assumption was that perception of experience as a source of knowledge varies depending on the level of education. We tested this hypothesis through One-Way ANOVA and learn that perception of experience as a source of knowledge differed significantly between education levels. The significance value comparing the groups was .000 so we confirmed our second hypothesis.

Further we tried to find out if there is a positive correlation between searching all possible ways for successful decision and positive experience with solving problems (H3) and between perception of experience as a source of knowledge and positive experience with solving problems (H4). We tested our last two hypotheses with Pearson's correlation coefficient. Based on our research and data collection we can argue that

Table 3: One-Way ANOVA for hypothesis two

\begin{tabular}{|c|c|c|c|c|c|}
\hline \multicolumn{6}{|c|}{ Experience are source of my knowledge } \\
\hline & Sum of Squares & df & Mean Square & $\mathrm{F}$ & Sig. \\
\hline Between Groups & 17,373 & 5 & 3,475 & 7,075 &, 000 \\
\hline Within Groups & 21,607 & 44 &, 491 & & \\
\hline Total & 38,980 & 49 & & & \\
\hline
\end{tabular}


Table 4: Pearson's correlation coefficient for hypothesis three

\begin{tabular}{|c|c|c|c|}
\hline & & $\begin{array}{l}\text { I try to find all possible ways for } \\
\text { successful decision }\end{array}$ & $\begin{array}{l}\text { I had positive experiences with solv- } \\
\text { ing the problems in past }\end{array}$ \\
\hline \multirow{3}{*}{$\begin{array}{l}\text { I try to find all possible ways for } \\
\text { successful decision }\end{array}$} & \multirow{3}{*}{$\begin{array}{l}\text { Pearson Correlation } \\
\text { Sig. (2-tailed) } \\
\text { N }\end{array}$} & 1 &, $381 * *$ \\
\hline & & & ,006 \\
\hline & & 50 & 50 \\
\hline \multirow{3}{*}{$\begin{array}{l}\text { I had positive experiences with } \\
\text { solving the problems in past }\end{array}$} & \multirow{3}{*}{$\begin{array}{l}\text { Pearson Correlation } \\
\text { Sig. (2-tailed) } \\
\text { N }\end{array}$} &, $381 * *$ & 1 \\
\hline & & ,006 & \\
\hline & & 50 & 50 \\
\hline
\end{tabular}

** Correlation is significant at the 0.01 level (2-tailed).

Table 5: Pearson's correlation coefficient for hypothesis four

\begin{tabular}{|c|c|c|c|}
\hline & & $\begin{array}{c}\text { Experience are source of my } \\
\text { knowledge }\end{array}$ & $\begin{array}{l}\text { I had positive experiences with solv- } \\
\text { ing the problems in past }\end{array}$ \\
\hline \multirow{3}{*}{$\begin{array}{l}\text { Experience are source of my } \\
\text { knowledge }\end{array}$} & \multirow{3}{*}{$\begin{array}{l}\text { Pearson Correlation } \\
\text { Sig. (2-tailed) } \\
\mathrm{N}\end{array}$} & 1 &, $429 * *$ \\
\hline & & & ,002 \\
\hline & & 50 & 50 \\
\hline \multirow{3}{*}{$\begin{array}{l}\text { I had positive experiences } \\
\text { with solving the problems } \\
\text { in past }\end{array}$} & \multirow{3}{*}{$\begin{array}{l}\text { Pearson Correlation } \\
\text { Sig. (2-tailed) } \\
\mathrm{N}\end{array}$} &, $429 * *$ & 1 \\
\hline & &, 002 & \\
\hline & & 50 & 50 \\
\hline
\end{tabular}

** Correlation is significant at the 0.01 level (2-tailed).

there is a positive correlation between searching all possible ways for successful decision and positive experience with solving problems as well as between perception of experience as a source of knowledge and positive experience with solving problems. Both correlations were confirmed at the 0,01 level.

Data collected from the sample of 50 respondents confirmed all four hypotheses set up on reviewed literature. Based on the reviewed literature and results from our research we can conclude that analyzing problems and use of experiences contribute to successful problem solving and decision.

Before conclusion several limitations of this study need to be considered. First, we used small representative sample and second, the discussed findings were obtained from single study, therefore generalizing the results should be done with caution. Also, important to point out is that respondents in the questionnaire evaluate themselves, which means that answers are their subjective opinion and it might depend on current circumstances and well-being. For further research it would also validate to use the research model of this paper on a bigger and diverse sample as well as restrict the samples to specific group and do a comparative analysis between the groups.

\section{Conclusion}

The main aim of this paper was to determine how in general individuals solve problems in their lives, and whether they use previous experiences as help in solving their problems. With the analysis we also tried to determine to what extent experience assist individuals in decision making process. Our research shows that individuals mainly believe that their experiences in solving problems personally enrich them and that experiences are source of their knowledge. Before decisionmaking they set a goal they want to achieve. Our research also shows that analyzing problems and use of experiences contribute to successful problem solving and decision. Therefore it is important to stress the role of experience and experiential learning in solving problems, which is the main emphasis of this paper.

To conclude, individuals are daily facing problem-solving. Despite that, the nature of the problems changed over the decades to a certain extent, mainly due to access to information and development of humanity itself. Individuals today are often not able to solve complex problems occurring in the workplace; therefore it is necessary to train them appropriately. Solving complex problems requires cooperation between 
various participants with different skills and with the aim of taking appropriate decisions. In this context, participants use different learning methods and techniques to solve complex problems, which assist individual in resolving work-related tasks and their related problems.

\section{References}

Bonwell, C. C. \& Eison, J. A. (1991). Active Learning: Creating Excitement in the Classroom. Washington, DC: The George Washington University (ERIC Clearinghouse on Higher Education).

Cavalluci, D. \& Eltzer, T. (2011) Structuring knowledge in inventive design of complex problems. Procedia Engineering, 9: 694-701, DOI: $10.1016 /$ j.proeng.2011.03.157

Chickering, A.W. \& Gamson, Z.F. (1987). Seven Principles for Good Practice. AAHE Bulletin, 39: 3-7.

Chen, X. L. \& Ding, F. (2010). Meta-Synthesis Approach to Model Complex Problem Solving, International Conference on E-Product E-Service and E-Entertainment (ICEEE), 7 - 9 Nov. 2010, DOI: 10.1109/ICEEE.2010.5660914

Dandurand, F., Shultz, T.R. \& Rey, A. (2012). Including cognitive biases and distance-based rewards in a connectionist model of complex problem solving. Neural Networks, 25: 41-56, DOI: 10.1016/j.neunet.2011.06.021

Dandurand, F., Shultz, T.R. \& Rivest, F. (2007). Complex problem solving with reinforcement learning, IEEE 6th International Conference on Development and Learning, pp. 157 - 162, 12. 13. July 2007, DOI: 10.1109/DEVLRN.2007.4354026

Erzar Metelko, D. (1999). Supervizija skozi proces učenja odraslih [Supervision through the process of adult learning]. In: Miloševič-Arnold, V., Vodeb-Bonač, M., Erzar-Metelko, D., Možina, M. (eds.). Supervizija - znanje za ravnanje. Ljubljana: Socialna zbornica.

Fowler, J. (2007). Experiential learning and its facilitation. Nurse Education Today, 28: 427-433. DOI 10.1016/j.nedt.2007.07.007

Jarvis, P. (2003). Izkustveno učenje in pomen izkušnje [Experience based learning and the importance of experience]. Sodobna pedagogika, 54(1): 94-103.

Keyser, M. W. (2000). Active learning and cooperative learning: understanding the difference and using both styles effectively. Research Strategies, 17: 35 - 44, DOI: 10.1016/S07343310(00)00022-7

Kim, M. K. (2012). Cross-validation study of methods and technologies to assess mental models in a complex problem solving situation, Computers in Human Behavior, 28: 703-717, DOI: 10.1016/j.chb.2011.11.018

Klashner, R. \& Sabet, S. (2007). A DSS Design Model for complex problems: Lessons from mission critical infrastructure, Decision Support Systems, 43: 990-1013, DOI: 10.1016/j. dss.2005.05.027
Leppävirta, J., Kettunen, H. \& Sihvola, A. (2011). Complex Problem Exercises in Developing Engineering Students' Conceptual and Procedural Knowledge of Electromagnetics, IEEE Transactions on Education, 54(1): 63 - 66, DOI: 10.1109/TE.2010.2043531

Marentič Požarnik, B. (2000), Psihologija učenja in pouka [Psychology of learning and Teaching], DZS, Ljubljana.

Meyer B. \& Scholl W. (2009). Complex Problem Solving after Unstructured Discussion: Effects of Information Distribution and Experience, Group Processes Intergroup Relations, 12: 495 - 515, DOI: $10.1177 / 1368430209105045$

Možina, S. (1991). Sociopsihologija v podjetju [Sociopsychology in Enterprises]. University of Ljubljana, Faculty of Economics.

Nuissl, E. (2006). Spreminjanje poučevanja in učenja v nadaljnjem izobraževanju [Change of teaching and learning in further education]. Sodobna pedagogika, 57(2): 12-22.

Pierrakos, O., Watson, H., Kander, R., Russell, J. \& Anderson, R. (2010). Special session - Not all problems are created equal: From problem-based learning theory to research on complex problem solving and implications for the engineering classroom. Frontiers in Education Conference (FIE), 2010 IEEE, pp. T3A1-T3A-3, 27-30 Oct. 2010, DOI: 10.1109/FIE.2010.5673220

Rosi B. \& Mulej M. (2006). Kako celoviteje prepoznavati, preprečevati in obvladovati probleme [How to comprehensively identify, prevent and manage problems]. Organizacija, 39: 35 - 49.

Tews, M., J., Michel, J., W. \& Noe, R., A. (2011). Beyond objectivity: The performance impact of the perceived ability to learn and solve problem., Journal of Vocational Behavior, 79(2): 484495, DOI: 10.1016/j.jvb.2010.11.005

Tuan, N.T. (2003.) On the complex problem: a study of interactive management. Kybernetes, 33(1): 62 - 79, DOI: $10.1108 / 03684920410514517$

Žnidaršič, J. \& Jereb, E. (2011). Innovations and Lifelong Learning in Sustainable Organization. Organizacija, 44: 185-194, DOI: 10.2478/v10051-011-0020-y

Mojca Bernik is Assistant Professor for Human Resource Management field on University of Maribor, Faculty of Organizational Sciences. She is Head of Human Resource Management Department. Her research field is strategic human resource management within organizations. She published research results in different publications in Slovenia and other countries.

Jasmina Žnidaršič is an assistant in the field of Management at the Faculty of Organizational Sciences, University of Maribor. Her research interests are mainly in the field of human resource management. She is the author or co-authored scientific articles published in domestic and foreign journals; her work was also presented at national and international professional and research conferences. 